\title{
Pelatihan Olahraga Futsal sebagai Sarana Mengurangi Aktivitas Game Online pada Anak-Anak di Kelurahan Mangunharjo
}

\author{
Yahya Eko Nopiyanto ${ }^{1^{*}}$, Septian Raibowo ${ }^{2}$ \\ 1,2Ilmu Pendidikan/Pendidikan Jasmani, Universitas Bengkulu, Indonesia, 38371 \\ E-mail: yahyaekonopiyanto@unib.ac.id \\ DOI: https://doi.org/10.37339/jurpikat.v1i2.264
}

Info Artikel:

Diterima:

2020-08-22

Diperbaiki:

2020-09-18

Disetujui:

2020-09-19

Kata kunci: Pelatihan, Futsal, Game, Online, Mangunharjo

\begin{abstract}
Abstrak: Permasalahan utama yang dihadapi mitra adalah meningkatnya aktivitas game online yang dilakukan oleh anak-anak di kelurahan Mangunharjo. Berdasarkan permasalahan yang dihadapi, maka dilakukan pelatihan olahraga futsal yang bertujuan untuk mengurangi aktivitas bermain game online pada anak-anak di kelurahan Mangunharjo. Peserta dalam kegiatan pelatihan ini adalah 25 anak laki-laki berusia antara 4-13 tahun. Tahapan dalam kegiatan ini adalah diskusi dengan karang taruna dan perangkat kelurahan Mangunharjo, pelatihan teknik dasar futsal, praktek dan pendampingan, turnamen futsal, evaluasi. Metode yang digunakan adalah collaborative learning, teaching game tournament, ceramah, demontrasi dan drill. Berdasarkan hasil pelatihan dan evalusi dapat disimpulkan bahwa pelatihan olahraga futsal sangat efektif sebagai sarana untuk mengurangi aktivitas bermain game online pada anak-anak di kelurahan Mangunharjo.
\end{abstract}

Abstract: Online game activities carried out by children in Mangunharjo village have increased. Based on the problems, futsal training was carried out which aims to reduce the activities of playing online games for children in Mangunharjo village. Participants in this training activity were 25 boys aged 4-13 years. The stages in this activity were discussions with youth organizations and Mangunharjo village officials, training in basic futsal techniques, practice and mentoring, futsal tournaments, and evaluation. The methods used were collaborative learning, 
teaching game tournament, lectures, demonstrations and drills. Based on the results of the training and evaluation, it can be concluded that futsal training was very effective as a

Keywords: Training, Futsal, means of reducing the activities of playing online games for Game, Online, Mangunharjo children in Mangunharjo village.

\section{Pendahuluan}

Perkembangan dunia teknologi memberikan pengaruh yang signifikan terhadap perkembangan dan pertumbuhan anak-anak di semua kalangan masyarakat. Dengan adanya teknologi, banyak game online berbayar yang bermunculan yang dapat diakses dengan mudah oleh anak-anak yang statusnya masih pelajar di sekolah dasar maupun sekolah menengah. Sehingga banyak anakanak yang mengisi waktu luangnya dengan bermain game online di handphone maupun di warung internet. Game online merupakan permainan komputer atau handphone yang dapat dimainkan oleh banyak pemain melalui internet. Dalam satu dekade terakhir, game online telah mengalami kemajuan yang sangat pesat. Hal tersebut dapat dilihat di kota-kota besar, tidak terkecuali juga kota-kota kecil bahkan sampai di pedesaan banyak sekali pusat game online yang muncul.

Banyak faktor yang menyebabkan anak-anak bermain game online diantaranya adalah kurangnya komunikasi yang baik antara orang tua dan anak, kurangnya pengawasan orang tua terhadap anaknya, kesalahan pola asuh yang diberikan orang tua terhadap anaknya, kejenuhan yang dialami oleh anak-anak dalam menjalani aktivitas sehari-hari. Tingginya intensitas bermain game online memberikan berbagai macam dampak atau pengaruh baik itu terhadap fisik maupun psikis anak-anak. Dampak fisik dapat berupa kelelahan pada anggota tubuh karena terlalu lama bermain game online yang menyebabkan kesehatan badan menurun sehingga mudah sakit. Sedangkan dampak psikis yang ditimbulkan yaitu individu menjadi mudah marah, tidak dapat mengontrol emosi yang disebabkan kekalahan dalam bermain game online (Kurniawan, 2017).

Survey di Indonesia menyebutkan remaja yang menggunakan internet yang memainkan game online sebanyak $35 \%$ dan sebanyak $55 \%$ pengguna game online adalah remaja pria (viva.co.id, 2013). Data pengguna internet aktif pada tahun 2014, diperkirakan pemain game online di Indonesia berkisar 10,7 juta orang atau sekitar $10 \%$ dari total pengguna. Jumlah pecandu game online di Indonesia diduga tertinggi di Asia dengan angka mencapi 14\% anak-anak Indonesia kecanduan game online (fk.ui.ac.id, 2020). Hal ini menunjukkan kemungkinan terjadinya peningkatan jumlah remaja yang bermain game online di Indonesia, sehingga dikhawatirkan dapat memberikan dampak negatif bila tidak terkendali. 
Kecanduan game online dapat dilihat dari penggunaan waktu rata-rata 20-25 jam dalam seminggu. Kecanduan game online dapat menyebabkan distorsi waktu, kurang perhatian, hiperaktif, tindakan kekerasan, emosi negatif, dan perilaku agresif. Kekerasan pada game online memungkinkan memiliki efek lebih kuat menimbulkan agresi terhadap remaja karena game online adalah permainan yang sangat menarik dan interaktif, game online memiliki permainan yang beberapa di antaranya berpola perilaku kekerasan, remaja akan berperilaku kekerasan berulang karena mereka sedang bermain dalam media game (Ardi, dkk, 2017). Hasil penelitian menunjukkan bahwa anak yang bermain video game aksi dengan unsur kekerasan mengalami peningkatan emosi sehingga berperilaku lebih agresif dan di samping itu juga rentan mengalami stress (Barseli \& Ifdil, 2017). Dampak negatif dari bermain game online bagi anak adalah sering bolos agar bisa bermain game online di warnet, prestasi akademik yang rendah, penggunaan uang jajan yang tidak tepat sebagaimana mestinya, jarang berolahraga dalam setiap minggu, dan boros jika mempunyai uang (Suryanto, 2015).

Mangunharjo adalah salah satu kelurahan yang ada di kecamatan Purwodadi, kabupaten Musi Rawas. Jumlah penduduk di kelurahan Mangunharjo terus mengalami peningkatan 3, 42\% setiap tahunnya, sehingga jumlah anak usia sekolah juga terus bertambah (BPS, Kabupaten Musi Rawas 2019). Namun pertambahan jumlah anak sekolah tersebut belum secara optimal didukung oleh pengetahuan orang tua mengenai dampak game online yang sering dimainkan oleh anak-anaknya. Terlebih lagi orang tua sering mengeluhkan sifat anak-anaknya yang sering menunda pekerjaan sekolah. Berdasarkan hasil observasi yang dilakukan oleh tim pengabdi dapat diketahui bahwa jumlah anak-anak yang bermain game online terus meningkat di kelurahan Mangunharjo. Hal ini dapat dilihat dari sering berkumpulnya anak-anak di area free wifi yang dipasang di balai kelurahan. Peningkatan jumlah ini tentu sangat berbahaya bagi kesehatan secara mental maupun fisik serta akan mempengaruhi prestasi akademik anak-anak di kelurahan Mangunharjo.

Untuk mengurangi dampak negatif dari penggunaan game online bagi anakanak di kelurahan Mangunharjo, maka diperlukan langkah yang tepat untuk menanggulangi dampak tersebut. Salah satu cara yang dilakukan oleh tim pengabdi adalah melakukan pelatihan olahraga futsal di kelurahan Mangunharjo. Futsal adalah permainan bola yang dimainkan oleh dua regu, yang masing-masing beranggota 5 orang. Tujuan dari pelatihan olahraga futsal di kelurahan Mangunharjo adalah sebagai sarana untuk mengurangi aktivitas bermain game online pada anak-anak di kelurahan Mangunharjo. Manfaat dari pelatihan olahraga 
futsal di Kelurahan Mangunharjo bagi anak-anak adalah: (1) mengurangi aktivitas anak dalam bermain game online sehingga menjadikan waktu luang lebih bermanfaat, (2) memicu pertumbuhan tulang dan otot anak sehingga meningkatkan prestasi akademik serta meningkatkan koordinasi gerak dan keseimbangan tubuh, (3) membantu anak belajar memimpin, bekerjasama, dan menjadi bagian dalam satu tim sehingga menjadi bekal bersosialisasi di masyarakat, (4) meningkatkan kemampuan sosial emosional anak sehingga menjadikan anak mudah bersosialiasasi dan tidak apatis terhadap lingkungan sekitar, (5) meningkatkan daya tahan tubuh, (6) meningkatkan fungsi otak, (7) mengurangi stress (Pane, 2015).

\section{Metode}

Pelatihan ini dilaksanakan di RT/RW 002/001, kelurahan Mangunharjo, kecamatan Purwodadi, kabupaten Musi Rawas. Pelatihan ini dilaksanakan pada bulan Januari-Maret 2020. Peserta pelatihan terdiri dari 25 anak laki-laki berusia antara 4-13 tahun. Pelatihan dilaksanakan dengan frekuensi 4 pertemuan dalam satu minggu dengan lama waktu pelatihan 90 menit setiap pertemuan. Bentuk kegiatan yang dilakukan adalah pelatihan dan pendampingan. Kegiatan dilakukan dengan model collaborative learning, teaching game tournament, ceramah, demontrasi dan drill. Teknik pengumpulan data menggunakan angket untuk mengetahui frekuensi anak dalam bermain game online. Teknik evaluasi atau analisis data dengan menggunakan perbandingan nilai rata-rata peserta antara sebelum dan sesudah pelatihan yang terdiri dari indikator belajar, disiplin, kerjasama, penggunaan game online, penggunaan handphone. Apabila terdapat perbedaan yang signifikan nilai rata-rata antara sebelum dan sesudah pelatihan maka program pelatihan olahraga futsal dianggap berhasil dalam mengurangi aktivitas game online bagi anak-anak di kelurahan Mangunharjo. Teknik analisis data disajikan pada tabel 1.

Tabel 1. Teknik Analisis Data

$\mathrm{X} 1$

Keterangan:

X1 : Nilai Rata-rata peserta sebelum pelatihan

$\mathrm{O}$ : Pelatihan futsal

X2 : Nilai Rata-rata peserta setelah pelatihan 


\section{Hasil dan Pembahasan}

Kegiatan pengabdian dilaksanakan dalam beberapa tahapan diantaranya adalah: 1) Diskusi dengan karang taruna dan perangkat kelurahan Mangunharjo, 2) pelatihan teknik dasar futsal, 3) praktek dan pendampingan, 4) turnamen futsal, 5) evaluasi.

\section{Pelaksanaan Diskusi Bersama Karang Taruna dan Perangkat Kelurahan Mangunharjo}

Diskusi dilaksanakan pada tanggal 4 Januari 2020. Diskusi membahas mengenai permasalahan yang sedang dihadapi oleh mitra di kelurahan Mangunharjo dan rencana pelaksanaan pelatihan futsal. Mitra mengharapkan adanya kegiatan pelatihan futsal untuk menambah pengetahuan dan keterampilan berolahraga serta mengurangi dampak negatif dari game online bagi anak-anak di kelurahan Mangunharjo. Hasil diskusi menyatakan bahwa kegiatan pelatihan akan dilaksanakan mulai tanggal 5 Januari 2020. Tempat yang dipilih sebagai pusat pelatihan adalah rumah Bapak Paino. Alasan pemilihannya dikarenakan Bapak Paino mempunyai halaman rumah yang luas dan layak digunakan untuk bermain futsal. Kegiatan pelatihan akan diawali dengan memberikan pelatihan teknik dasar permainan olahraga futsal. Menurut Laksana (2011: 44) menyatakan bahwa teknik dasar permainan futsal yang harus dikuasai ada enam yaitu passing, control, chipping, dribbling, heading dan shooting.

\section{Pelatihan Teknik Dasar Futsal}

Pelatihan teknik dasar futsal dilaksanakan dengan cara membagi kelompok kecil yang terdiri dari lima anak dalam setiap kelompoknya. Materi pelatihan teknik dasar futsal terdiri dari:

\section{1) Passing dan Controlling}

Passing adalah salah satu teknik dasar permainan futsal yang sangat dibutuhkan oleh setiap pemain, karena dengan lapangan yang sangat rata dan ukuran lapangan yang kecil dibutuhkan passing yang keras dan akurat. Menurut Lhaksana (2011: 30) menyatakan bahwa di lapangan yang rata dan ukuran lapangan yang kecil dibutuhkan passing yang keras keras dan akurat karena bola yang meluncur sejajar dengan tumit pemain. Keberhasilan mengumpan ditentukan oleh kualitasnya, tiga hal dalam kualitas mengumpan yaitu keras, akurat dan bisa diterima oleh teman kita. Sedangkan controlling adalah kemampuan pemain saat menerima bola sampai pemain tersebut akan melakukan gerakan selanjutnya terhadap bola seperti mengumpan, menggiring, ataupun menembak bola kearah gawang. 
Pelatihan teknik passing dan controlling dilaksanakan pada tanggal 5-18 Januari 2020. Pada saat pelatihan, tim pengabdi bekerjasama dengan pemuda karang taruna kelurahan Mangunharjo. Pelatihan teknik dasar passing dilakukan dengan cara, yaitu (1) tim pengabdi membagi kelompok kecil yang terdiri dari 4-6 anak, (2) latihan passing dan controlling dilakukan secara drill selama 30 menit, (3) dilanjutkan dengan bermain futsal selama 30 menit, (4) pada saat anak-anak dilatih, tim pengabdi melakukan pengamatan terhadap anak-anak dalam melakukan permainan futsal.

\section{2) Chipping dan Dribbling}

Chipping adalah gerakan menendang bola yang lebih mengutamakan akurasi tendangan tanpa menggunakan kekuatan dan kecepatan tendangan (Susworo, 2009). Sedangkan dribbling merupakan tendangan bola putus-putus atau pelan-pelan (Jaya, 2008: 66). Pelatihan teknik chipping dan dribbling dilaksanakan pada tanggal 20-25 Januari 2020. Pada saat pelatihan, tim pengabdi bekerjasama dengan pemuda karang taruna kelurahan Mangunharjo. Pelatihan teknik dasar chipping dan dribbling dilakukan dengan cara, yaitu: (1) tim pengabdi membagi kelompok kecil yang terdiri dari 4-6 anak, (2) latihan chipping dan dribbling dilakukan secara drill selama 30 menit, (3) dilanjutkan dengan bermain futsal selama 30 menit, (4) pada saat anakanak dilatih, tim pengabdi melakukan pengamatan terhadap anak-anak dalam melakukan permainan futsal.

\section{3) Shooting dan Heading}

Shooting merupakan teknik dasar yang harus dikuasai oleh setiap pemain, teknik ini merupakan cara untuk menciptakan gol dan memenangkan pertandingan. Menurut Lhaksana (2011: 34) shooting memiliki ciri khas laju bola yang sangat cepat dan keras serta sulit diantisipasi oleh penjaga gawang. Pentingnya menyundul bola dalam permainan futsal tidak seperti dalam permainan sepak bola konvensional, tetapi ada situasi dimana pemain perlu menggunakan teknik menyundul bola untuk menghalau bola dari serangan lawan dan dalam menciptakan gol. Menurut Irawan (2009: 37) tujuan dari menyundul bola adalah untuk mengumpan, mencetak gol dan mematahkan serangan lawan atau membuang bola. Pelatihan teknik shooting dan heading dilaksanakan pada tanggal 27- 1 Februari 2020. Pada saat pelatihan, tim pengabdi bekerjasama dengan pemuda karang taruna kelurahan Mangunharjo. Pelatihan teknik dasar shooting dan heading dilakukan dengan cara, yaitu: (1) tim pengabdi membagi kelompok kecil yang terdiri dari 4-6 anak, (2) latihan shooting dan heading dilakukan secara drill selama 30 menit, (3) dilanjutkan dengan bermain futsal selama 30 menit, (4) pada saat anak-anak dilatih, tim pengabdi melakukan pengamatan terhadap anak-anak dalam melakukan permainan futsal. 


\section{Praktek dan Pendampingan}

Setelah materi pelatihan tentang teknik dasar futsal selesai dilaksanakan, maka kegiatan selanjutnya adalah praktek dan pendampingan. Praktek yang dimaksudkan adalah anak-anak mendemontrasikan materi-materi yang telah diberikan ke dalam permainan futsal. Kegiatan praktek dilakukan pada tanggal 3-15 Februari 2020. Praktek selama 2 minggu dengan frekuensi 6 kali pertemuan, setiap pertemuan mempunyai durasi waktu 90 menit. Setiap pertemuan diawali pada pukul 16.00 dan diakhiri pada pukul 17.30. Selama kegiatan praktek 2 minggu tersebut, tim pengabdi terus melakukan pendampingan untuk mengetahui kemajuan yang telah dicapai oleh anak-anak dan untuk mengetahui bagaimana dampak pelatihan futsal terhadap aktivitas game online. Foto bersama setelah kegiatan praktek dan pendampingan disajikan pada Gambar 1.

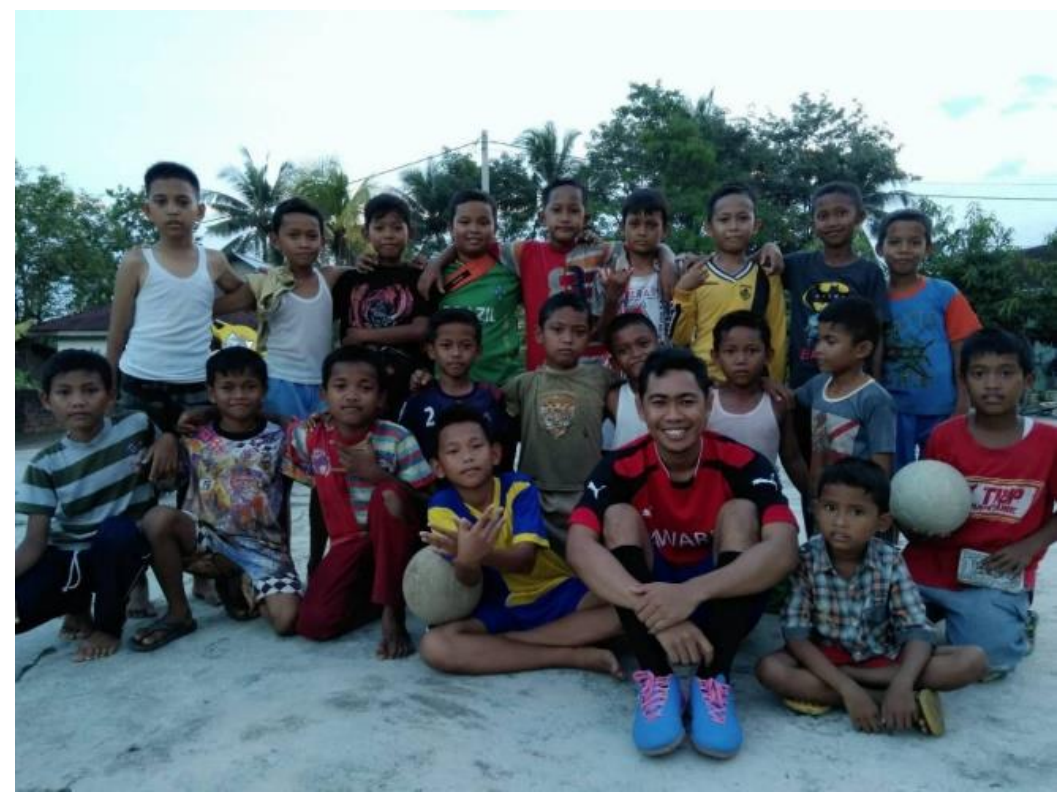

Gambar 1. Foto bersama setelah kegiatan praktek dan pendampingan

\section{Turnamen Futsal}

Turnamen futsal merupakan puncak dari kegiatan pelatihan ini. Turnamen diikuti oleh semua anak-anak yang menjadi peserta pelatihan yang terdiri dari 25 anak. Peserta tersebut dibagi menjadi 5 tim yang masing-masing tim terdiri dari 5 anak. Tim 1 dengan nama Deltras FC, Tim 2 dengan nama Kidul FC, Tim 3 dengan nama Wetan FC, Tim 4 dengan nama Srigala Kidul FC, Tim 5 dengan nama Trabas FC.

Turnamen ini dilaksanakan pada tanggal 17- 23 Februari. Turnamen ini bertujuan untuk memberikan kegembiraan bagi semua peserta pelatihan dan mengurangi frekuensi penggunaan game online di handphone. Dengan adanya 
turnamen, anak-anak dapat menyalurkan semua energi berlebihnya kepada aktivitas olahraga yang positif.

Berdasarkan hasil pengamatan pada saat turnamen, semua peserta sangat gembira dan begitu berantusias untuk mengikuti rangkaian kegiatan turnamen tersebut. Terdapat pemandangan yang sangat menarik pada saat turnamen berlangsung, yaitu semua peserta tidak menggunakan handphone untuk bermain game online, semua peserta sangat antusias untuk mendukung temannya yang sedang bertanding. Sebagian handphone disimpan di tas masing-masing, dan sebagian lainnya digunakan untuk merekam jalannya pertandingan. Setelah melalui persaingan yang sengit, akhir terdapat 3 tim yang menjadi juara. Juara 1 adalah tim Deltras FC, juara 2 adalah tim Srigala Kidul FC, dan juara 3 adalah Trabas FC.

\section{Evaluasi}

Setelah semua rangakaian aktivitas pelatihan selesai dilaksanakan maka tim pengabdi melakukan evaluasi kegiatan. Tujuan dari evaluasi adalah untuk mengetahui besarnya kontribusi pelatihan futsal terhadap aktivitas game online pada anak-anak di kelurahan Mangunharjo. Evaluasi dilaksanakan dengan menganalisis hasil pengamatan dan hasil dari pengumpulan data menggunakan angket. Hasil evaluasi disajikan pada tabel 2.

Tabel 2. Hasil Evaluasi Program Sebelum dan Sesudah Pelatihan

\begin{tabular}{lll}
\hline Indikator & \multicolumn{2}{c}{ Penilaian } \\
\cline { 2 - 3 } & Pre-test & Post-test \\
\hline Belajar & $25 \%$ & $60 \%$ \\
\hline Disiplin & $30 \%$ & $70 \%$ \\
\hline Kerjasama & $35 \%$ & $80 \%$ \\
\hline Game online & $80 \%$ & $20 \%$ \\
\hline Handphone & $75 \%$ & $25 \%$ \\
\hline
\end{tabular}

Berdasarkan pada tabel 2. dapat diketahui bahwa hasil evaluasi menggambarkan bahwa hasil pelatihan futsal memberikan dampak positif anakanak di kelurahan Mangunharjo. Pada indikator belajar terjadi peningkatan dari 25\% menjadi $60 \%$. Artinya adalah terjadi peningkatan yang signifikan, anak-anak yang sebelum mengikuti pelatihan sangat malas untuk belajar, dan setelah mengikuti pelatihan anak-anak menjadi rajin belajar. Hal ini terjadi karena, tim pengabdi selalu memberikan motivasi bagi anak-anak peserta pelatihan sehingga mampu membangkitkan minat belajar. Dalam rangka mencegah dampak negatif dalam bermain game online yang berlebihan pada anak-anak di kelurahan Mangunharjo 
maka perlu adanya tindakan yang dilakukan oleh semua pihak yang bertanggung jawab dalam perkembangan anak. Adapun pihak-pihak yang berperan dalam mengurangi aktivitas bermain game online, yaitu: keluarga (orangtua), lingkungan masyarakat, sekolah (kepala sekolah, guru mata pelajaran pendidikan jasmani, guru bimbingan dan konseling).

Pada indikator disiplin, terdapat peningkatan yang signifikan dari $30 \%$ menjadi $70 \%$. Artinya adalah anak-anak semakin sadar akan pentingnya disiplin. Hal ini terjadi karena tim pengabdi selalu memberikan motivasi akan pentingnya disiplin bagi kesuksesan seseorang. Hal ini terbukti bahwa kedisplinan seseorang akan terbentuk melalui olahraga (Sarwono, 2014). Untuk membentuk kedisiplinan anak-anak maka peran keluarga dan guru pendidikan jasmani di sekolah sanagt dibutuhkan. Berkaitan dengan peran guru guru pendidikan jasmani dalam masalah mengurangi aktivitas bermain game online yang berlebihan, olahraga tim atau kelompok merupakan salah satu cara untuk mengatasi masalah tersebut. Dalam olahraga tim, anak-anak akan diajarkan banyak nilai-nilai luhur seperti, disiplin, kerjasama, saling menghargai, dan sebagainya.

Pada indikator kerjasama, terdapat peningkatan positif yang signifikan. Artinya anak-anak menjadi lebih mudah untuk bekerjasama dalam sebuah tim. Hal ini dikarenakan olahraga futsal adalah olahraga tim yang sangat membantu untuk menanamkan nilai kerjasama bagi anak-anak. Bukan hanya itu saja, anak-anak yang dulunya apatis karena disebabkan game online, setelah mengikuti pelatihan menjadi lebih mudah bergaul dan bekerjasama. Keberhasilan ini tidak terlepas dari metode cooperative learning yang menekankan pada diskusi sehingga dapat mengurangi kebiasaan bermain game online (Fauziawati, 2015). Tujuan penggunaan cooperative learning dalam diskusi kelompok dalam mengurangi kebiasaan bermain game online dapat mendorong anak-anak untuk menggunakan pengetahuan dan pengalamannya dengan memanfaatkan informasi yang diperoleh selama mengikuti diskusi kelompok guna memecahkan masalah khususnya yang berkaitan dengan olahraga futsal dan kebiasaan anak-anak bermain game online. Anak-anak menceritakan kebiasaan bermain game online serta alasan mereka bermain game online dan mencari solusi pemecahan masalah agar kebiasaan game online menjadi berkurang. Diskusi kelompok tidak hanya memecahkan masalah, tetapi juga mengembangkan kepribadian anak, dan memupuk kerjasama bagi anak-anak.

Pada indikator game online, terjadi penurunan yang signifikan. Artinya anakanak secara bertahap sadar akan bahaya dan dampak negatif dari game online yang sering dimainkannya. Para peserta juga dibekali dengan pengetahuan pengaruh game online terhadap minat belajar (Johan, 2019). Pada saat pelatihan anak-anak 
diberikan pengetahuan oleh tim pengabdi akan bahayanya game online bagi kesehatan jasmani dan rohani. Pada pelatihan ini juga anak-anak dibekali dengan pengetahuan mengenai manfaat dari berolahraga futsal bagi kesehatan jasmani dan rohani. Tujuan diskusi kelompok dalam pelatihan ini adalah melatih keberanian anak-anak untuk berani menyumbangkan buah pikirannya dengan cara ikut memberikan pendapat dalam diskusi kelompok mengenai bahaya game online, dan manfaat olahraga futsal untuk mengurangi aktivitas bermain game online. Selain itu membantu anak-anak mengembangkan keterampilan bermain futsal dan keterampilan dalam mengemukakan pendapatnya secara jelas dan terarah sehingga dapat mengurangi kebiasaan anak-anak bermain game online. Melalui olahraga futsal anak-anak dapat mengalihkan aktivitas bermain game online pada kegiatan yang positif, hal ini sangat penting sebagai upaya mengurangi bermain game online pada anak-anak di kelurahan Mangunharjo.

Pada indikator handphone, terdapat penurunan dari 75\% menjadi 25\%. Artinya anak-anak menjadi lebih bijak dalam menggunakan handphone. Dalam pelatihan ini anak-anak diarahkan untuk menggunakan handphone sebagai media pembelajaran yang interaktif bukan untuk bermain game online. Berdasarkan beberapa penelitian menyatakan bahwa media pembelajaran interaktif dapat meningkatkan hasil belajar pendidikan jasmani (Pratama, 2017). Bukan hanya itu saja, guru juga disarankan membekali dirinya lebih baik lagi dalam memanfaatkan dan mengembangkan media pembelajaran untuk mengatasi permasalahan yang terjadi selama proses belajar mengajar berlangsung, sehingga tercipta suasana belajar yang menyenangkan tanpa mengurangi nilai dari materi pelajaran yang sedang disampaikan (Arditama, 2015). Jadi dapat diketahui bahwa pelatihan olahraga futsal yang menekankan pada cooperative learning dapat mengurangi aktivitas bermain game online melalui handphone pada anak-anak di kelurahan Mangunharjo.

\section{Kesimpulan}

Berdasarkan hasil pelatihan dan evaluasi dapat disimpulkan bahwa pelatihan olahraga futsal sangat efektif sebagai sarana untuk mengurangi aktivitas bermain game online pada anak-anak di kelurahan Mangunharjo.Tim pengabdi memberikan saran sebagai berikut:

a. Disarankan pelatihan futsal tetap dilaksanakan secara rutin oleh pemuda karang taruna dan perangkat kelurahan Mangunharjo.

b. Memberikan pengawasan dan bimbingan yang intensif kepada anak-anak agar lebih termotivasi dalam berolahraga dan mengurangi aktivitas game online. 


\section{Ucapan Terima Kasih}

Tim pengabdi mengucapkan terima kasih kepada perangkat kelurahan Mangunharjo dan karang taruna Mangunharjo yang telah bersedia membantu pelaksanaan pengabdian ini.

\section{Referensi}

Arditama, H. (2015). Pengembangan Multimedia Pembelajaran Interaktif (Mpi) Materi Permainan Bola Voli Untuk Kelas 5 Di Sd Tlogorejo 3 Demak(Doctoral dissertation, UNIVERSITAS NEGERI Semarang).

Ardi, Z., Putra, M. R. M., \& Ifdil, I. (2017). Ethics And Legal Issues In Online Counseling Services: Counseling Principles Analysis. Jurnal Psikologi Pendidikan dan Konseling: Jurnal Kajian Psikologi Pendidikan dan Bimbingan Konseling, 15-22.

Badan Pusat Statistik Kabupaten Musi Rawas. (2019). Kecamatan Purwodadi Dalam Angka.

Barseli, M., \& Ifdil, I. (2017). Konsep Stres Akademik Siswa. Jurnal Konseling dan Pendidikan, 5(3), 143-148.

Fauziawati, W. (2015). Upaya Mereduksi Kebiasaan Bermain Game Online Melalui Teknik Diskusi Kelompok. 4(2), 115-123.

Irawan, A. (2009). Teknik Dasar Modern Futsal. Jakarta: Pena Pundi Aksara.

Jaya, A. (2008). Futsal Gaya Hidup, Peraturan, dan Tips-Tips Permainan. Yogyakarta: Pustaka Timur.

Johan. (2019). Pengaruh Game Online Terhadap Minat Untuk Belajar Peserta Didik Kelas X di MA Al Hidayah Depok. Research and Development Journal Of Education, 5(2), 12-25.

Kurniawan. (2017). Pengaruh Intensitas Bermain Game Online Terhadap Perilaku Prokrastinasi Akademik Pada Mahasiswa Bimbingan Konseling. Jurnal Koseling Gusjigang, 3(1), 1-8. https://doi.org/10.24176/jkg.v3i1.1120.

Pratama, R. Y. (2017). Pengembangan Media Interaktif Menggunakan Aplikasi Adobe Macromedia Flash 8 Pada Mata Pelajaran Penjas Kelas VIII SMP di Padang Pariaman (Doctoral dissertation, Universitas Negeri Padang).

Lhaksana, J. (2011). Taktik \& Strategi Futsal Modern. Jakarta: Penebar Swadaya Group. Pane, B. S. (2015). Peranan Olahraga Dalam Meningkatkan Kesehatan. Jurnal Pengabdian Kepada Masyarakat, 21(79), 1-4. https://jurnal.unimed.ac.id/2012/index.php/jpkm/article/view/4646

Sarwono, S. (2014). Meningkatkan Aktivitas Belajar dan Disiplin Siswa dalam Pembelajaran Pendidikan Jasmani. Phederal: Physical Education, Health and Recreation Journal, 8(1), 13936.

Suryanto, R. N. (2015). Dampak Positif Dan Negatif Permainan Game Online Dikalangan Pelajar. Jom FISIP, 2(2), 1-15. 